\title{
KOMUNIKACIJSKA KAMPANJA ISLAMSKE DRŽAVE: DABIQ, 2014-2015.
}

\author{
Boris Havel \\ Fakultet političkih znanosti \\ Sveučilišta u Zagrebu \\ E-mail: bhavel@fpzg.hr
}

\author{
DOI: 10.20901/an.14.10 \\ Pregledni rad \\ Primljeno: studeni 2017.
}

\begin{abstract}
Sažetak Sadržaj i poruke komunikacijske kampanje Islamske države od proglašenja kalifata u srpnju 2014. do kraja 2015. bitno su drukčiji od promidžbe i komunikacije drugih poznatih islamističkih skupina s Bliskog istoka. Pozornost su isprva plijenile bolja kvaliteta produkcije i nezamisliva morbidnost prizora. No važnija je razlika u idejnom sadržaju i autentičnosti motiva, metoda i ciljeva. Islamska država obraća se muslimanima koji su upućeni u kanonske tekstove, normativne tradicije i autoritativna tumačenja islamske vjere i zakona. Oni prihvaćaju mnoga temeljna načela radikalnog tumačenja islama, no trebalo ih je uvjeriti u to da Islamska država obnovlja legitimni kalifat i da je Abu Bakir El Bagdadi istinski amirul-muminin. U komunikacijskoj kampanji 2014-2015. upadljivo je bilo nepozivanje na ideološke razloge ili pritužbe zbog ekonomske, kolonijalne, nacionalne, rasne ili druge ugroženosti. Pokazana je i posvemašnja nezainteresiranost za stvaranje pozitivne slike o sebi među nemuslimanima i umjerenim muslimanima na Zapadu i drugdje. Ako Zapad prepozna razinu autentičnosti kojom se u komunikacijskoj kampanji predstavljaju motivi, sredstva i ciljevi Islamske države, studiozniji pristup mogao bi biti važan korak u suzbijanju ideje kalifata i njegova utjecaja na islamski svijet.
\end{abstract}

Ključne riječi Islamska država, Bliski istok, islamizam, terorizam, kalifat, komunikacijska kampanja

Bliski je istok u posljednjih nekoliko desetljeća iznjedrio mnoge neočekivane političke fenomene i aktere, a jedan od najupečatljivijih i najopasnijih zasigurno je kalifat Islamske države (ID $\left.{ }^{1}\right)$, proglašen u Mosulu 29. srpnja 2014. Zapad

1 Pokrata za Islamsku državu nije preuzeta iz engleskog jezika. Općenito je neispravno u tekstovima na hrvatskom jeziku rabiti uvriježene pokrate ISIS i ISIL. Osim što nisu u duhu hrvatskoga jezika, te su pokrate zastarjele jer se odnose na Islamsku državu Iraka i Sirije odnosno Levanta, kako se Islamska država nazivala prije proglaše-

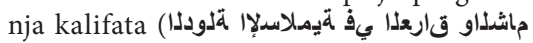
odnosno aldaulat alislamija fi al-irak ualšam). su iznenadili mnogi aspekti njegova nastanka i djelovanja, a jedan od najvažnijih bila je velika privlačnost novoosnovanog kalifata mnogim muslimanima u svijetu. Tome je uvelike pridonijela učinkovita komunikacijska kampanja te terorističke kvazidržavne organizacije. Suprotno prilično uobičajenoj percepciji da vjerskom radikalizmu kao obliku političke borbe pribjegavaju neobrazovani očajnici iz siromašnih krajeva svijeta, Islamska država uspjela je privući tisuće pristaša koji se ne uklapaju u taj profil. Primjerice, u središnjem dnevniku Švedske televizije 10. studenoga 2015. objavljen je podatak Švedske taj- 
ne službe (Säpo) prema kojemu je 286 švedskih državljana otputovalo u Siriju i priključilo se "terorističkim skupinama poput ID-a", a trećina su bile žene. U borbama je poginulo 40, a 125 osoba vratilo se u Švedsku. ${ }^{2}$ I državljani drugih zapadnoeuropskih država preselili su se u Siriju i Irak kako bi pridonijeli stvaranju Islamske države. Do kraja 2015. oko 5.000 boraca iz zapadnih i oko 25.000 iz arapskih država borilo se u Iraku i Siriji na strani Islamske države (Byman 2016: 79). Deseci islamističkih pokreta te brojni pojedinci iz raznih država prisegnuli su na odanost kalifu Abu Bakiru El Bagdadiju. Usto, tisuće muslimanskih stručnjaka s različitih područja, kao što su medicina i računarstvo, iz mnogih se krajeva svijeta doselilo u Islamsku državu. Do sredine 2015. kalifat se prostirao na području većem od Velike Britanije, a unutar njegovih fluidnih granica živjelo je oko osam milijuna ljudi. Ništa slično nije zabilježeno u novijoj povijesti Bliskog istoka.

I druge su islamističke skupine nadzirale ili nadziru velika područja pa vode i cijela društva. Talibani su od 1996. do 2001. upravljali emiratom u Afganistanu. Al Kaida je nadzirala područja u Sudanu, Afganistanu, Siriji, Iraku i Jemenu. Hamas je na izborima 2006. došao na vlast u Pojasu Gaze. Šijitski Hezbolah je u južnom Libanonu stvorio "svojevrsnu državu u državi" (Kasapović 2016: 245). No sve te skupine mogu postojati - i postojale su - i bez nadzora teritorija, u ilegalnosti ili kao opozicija vlasti, što kalifat ne može: njegovo je postojanje nužno povezano s vojnom i političkom upravom nad teritorijem, i to teritorijem koji se širi (Wood 2015: 7894). Okosnicu navedenih organizacija uglavnom čine lokalne etničko-vjerske skupine: Paštuni, Palestinci, libanonski

SVT Rapport 10/11 19.30, od 15:02 do 15:23 (http://www.svtplay.se/video/4622577/rapport/rapport-1770?start=auto, pristupljeno 11. studenoga 2015). šijiti i drugi. Osim što su se borile za neposredne lokalne političke, vojne i socijalne ciljeve, te su skupine pokazivale ambiciju uključivanja u šira, katkad i globalna, zbivanja. Njihove su komunikacijske i propagandne kampanje osmišljene radi novačenja članova, ali i objašnjavanja razloga svoga postojanja i ciljeva borbe široj svjetskoj javnosti, uključujući nemuslimane. Sve su te organizacije na različitim područjima i u različitu opsegu svojima informacijskim i propagandnim kampanjama postigle određeni uspjeh. No između komunikacijske kampanje Islamske države i drugih islamističkih pokreta postoji duboko razilaženje koje ukazuje na razlike u samopercepciji, pogledima na ostatak svijeta, tijek povijesti i eshatologiju.

Islamska država nov je političko-religijski fenomen i o njemu još nema dovoljno podataka kako bi se kvalitetno znanstveno proučavao (Hosken 2015: 14). ${ }^{3} \mathrm{O}$ nizu aspekata sustava vodstva, administracije i strategija može se govoriti uglavnom hipotetski. No komunikacijska kampanja zahvalnije je polje istraživanja. Islamska država ulaže značajna sredstva u proizvodnju i širenje promišljene i sugestivne promidžbe za koju je zadužen Al Hayāt Media Center koji proizvodi iznimno kvalitetne video i audio-materijale te časopise na nekoliko jezika. Osim sekundarnih izvora, u ovome članku ponajprije ću se referirati na službeno glasilo Islamske države, časopis Dabiq, koji je do sredine 2016. objavljen u 15 brojeva, a potom je zamijenjen

\footnotetext{
V. intervju s Aymennom Jawadom al-Tamimijem o temi vjerodostojnosti dokumentacije čiji je navodni autor Islamska država. Autor objašnjava i zašto će se kvalitetna znanstvena studija moći napraviti tek nakon određenoga vremenskog odmaka i pristupa dokumentaciji. https://www. washingtonpost.com/news/worldviews/ wp/2015/12/30/leaked-documents-may-reveal-the-inner-workings-of-the-islamic-state-but-what-if-they-are-fake (pristupljeno 30. prosinca 2015).
} 
časopisom Rumiyah. ${ }^{4}$ Poruke iz Dabiqa usporedit ću s porukama Hamasove Povelje, Hezbolahova Manifesta, Al Kaidina časopisa Inspire i časopisa Haqiqah britanske organizacije Imams Online kojim islamski teolozi nastoje odvratiti muslimane od pristupanja terorističkim skupinama, poglavito Islamskoj državi.

\section{Hamasova i Hezbolahova kampanja}

Hamas je jedna od prvih islamističkih skupina koja je svoje ciljeve i ideologiju stavila na uvid široj javnosti. To je učinjeno 1988, godinu dana nakon osnutka pokreta, objavljivanjem Povelje koja sadržava 36 članaka..$^{5}$ Glavna je tema Povelje beskompromisna borba za oslobođenje Palestine, koja se ponajprije tumači kao vjerska dužnost. Prema čl. 8, "Alah je cilj, Prorok je model, Kuran je ustav, džihad je put, a smrt za Alahovu stvar je (naše) najuzvišenije vjerovanje". Poveljom se ne predviđa mogućnost postizanja mirnog sporazuma s Izraelom (čl. 13): "Mirovne inicijative, takozvana mirovna rješenja i međunarodne konferencije za rješenje palestinskog problema, kose se s vjerovanjem Islamskog pokreta otpora. Odreći se bilo kojeg dijela Palestine znači odreći se dijela religije..." U čl. 13. tvrdi se kako "nema rješenja za palestinski problem osim putem džihada", a u čl. 15. da "u umove budućih naraštaja muslimana moramo utisnuti da je palestinski problem religijski problem, koji se na toj osnovi ima i riješiti". Znakovita je i tvrdnja iz čl. 28. kako "Izrael, time što je židovski i što je nastanjen Židovima, prkosi islamu i musli-

4 U ovome članku ne referiram se na internetske video-uratke Islamske države, ponajprije zbog njihove prekomjerne brutalnosti. Tekstovi iz Dabiqa dovoljni su za kvalitetnu analizu komunikacijske kampanje.

5 Cjelovit prijevod Povelje na engleski preuzet je iz: Stav 2001: 391-405. Više o Hamasovoj povelji u: Havel 2013: 555-558, odakle su preuzeti prijevodi dijelova na hrvatski. manima". U čl. 7. Hamas priziva hadis, prema kojemu "neće nastupiti Sudnji dan sve dok se muslimani ne budu borili protiv Židova. Pa će ih muslimani ubijati, tako da će se Židovi skrivati iza drveća i kamenja. Kamen i drvo će govoriti: 'O, muslimane, evo Židova iza mene, dođi i ubij ga'. Osim drveta Garkad, jer ono je židovsko drvo". Taj hadis potječe iz dviju najvažnijih zbirki hadisa, Buharijeve i Muslimove, ali se njegova tema - eshatologija - u sunitskom islamu, u usporedbi sa šijitskim, razmjerno rijetko pojavljuje u tekstovima s izrazito političkom porukom.

Premda religijski argumenti čine okosnicu Povelje, ipak nisu jedini. U Povelji ima tvrdnja i teza s kojima se može poistovjetiti mnogo širi krug potencijalnih simpatizera, uključujući one izvan muslimanske zajednice. Tako se u čl. 20. i 21. naglašavaju važnost "socijalne solidarnosti" i dužnost članova Hamasa da brinu za "interese masa". Nacionalizam (wataniyya) u čl. 12. prikazuje se kao dio religije i kao borba za "domovinu". Iz Povelje se uglavnom iščitava kako je ta domovina ograničena na Palestinu (čl. 15). Za "uzurpiranje nekih islamskih zemalja" krivi su orijentalisti i misionari, odnosno imperijalizam (čl. 15). Znakovite su klasične protužidovske i protusemitske optužbe koje je izvorno iznjedrio kršćanski svijet i koje nisu sukladne ranoislamskima i kanoniziranim islamskim viđenjem Židova. Prema njima, Židovi, umreženi u javne i tajne organizacije, šire nemoral i potkopavaju društva kako bi njima ovladali. Židovske su urote opisane u Protokolima cionskih mudraca (čl. 22). Implicitne optužbe da su Židovi stajali iza Francuske i komunističke revolucije, izazvali Prvi i Drugi svjetski rat, kolonizirali druge zemlje posredstvom financijske kontrole imperijalnih država, eksploatirali bogatstva kolonija, širili korupciju te uspostavili UN i Vi- 
jeće sigurnosti radi lakšeg upravljanja svijetom (Havel 2013: 557) značajno odstupaju od ranoga i klasičnog islamskog viđenja Židova kao opakih, ali politički i vojno impotentnih ljudi (Havel 2014: 221-243). Nadalje, Hamas sebe smatra univerzalnim pokretom (čl. 7) i predvodnikom borbe protiv svjetskog cionizma (čl. 32). Istodobno, u više je navrata pregovarao s Izraelom i potpisivao primirja kojih se donekle držao. Usto, budući da Hamas u posljednjih nekoliko godina pred svjetskom javnošću naglašava ideološke i teritorijalne aspekte sukoba nauštrb religijskih tema, razumijevanje na koje nailazi u Europi nije nebitno. Među ostalim, Hamas je podnio tužbu protiv Vijeća Europske unije i tražio da se izbriše s popisa terorističkih organizacija kojima se zamrzavaju financijska sredstva. Opći sud je presudom 17. prosinca 2014. poništio odluke i uredbe Vijeća koje se odnose na Hamas, uključujući njegovo vojno krilo Izz al-Din al-Qassem, ${ }^{6}$ no kako je uložena žalba, presuda nije stupila na snagu. Hamas je slao oprečne poruke o sebi. U teoriji se predstavljao kao beskompromisna islamistička organizacija koja odbacuje pregovore, ali kada je to dovoljno oportuno ipak pregovara, a vjerska načela - poput nepriznavanja nevjerničkih sudova ili nesudjelovanja na parlamentarnim izborima - podređuje pragmatičnim ciljevima.

Važan je čimbenik Hamasova postojanja socijalno djelovanje. Humanitarni, zdravstveni i obrazovni aktivizam bitno je pridonio porastu popularnosti te organizacije među palestinskim stanov-

Tekst presude na hrvatskom dostupan je na: http://curia.europa.eu/juris/document/document.jsf;jsessionid=9ea7d0f13 0d529ff31baea9e4d2b80f7ed4bcf57e1d9. e34KaxiLc3eQc40LaxqMbN4Oc38Oe0 ?text $=\&$ docid $=162356 \&$ pageIndex $=0 \&$ do clang $=$ HR \& mode $=$ req \&dir $=\&$ occ $=$ first $\&$ part=1\&cid=676539 (pristupljeno 21. prosinca 2015). ništvom koje je umorno od Fatahove "kleptokratske" vladavine (Havel 2013: 558; usp. i Kasapović 2016a: 289-290). Budući da je Hamas palestinski ogranak Muslimanskog bratstva, takav aktivizam nije neočekivan; neki autori smatraju kako je primaran fokus Muslimanskog bratstva upravo socijalni aktivizam (Jensen 2009: 8). ${ }^{7}$ Društveni angažman i društvena odgovornost, kombinirani s islamizmom, učinili su Hamas privlačnim većini stanovnika Gaze, kako se pokazalo na izborima 2006. Kasnijem smanjenju popularnosti pridonijelo je sve lošije materijalno stanje stanovništva Gaze, za što je uvelike odgovorna Hamasova uprava.

Hezbolah u svojem Manifestu iz $2009 .{ }^{8}$ još jače naglašava ideološke nauštrb vjerskih argumenata. Manifest te radikalne šijitske skupine u mnogim ulomcima više nalikuje na komunistički pamflet nego na islamistički program. Protuamerički sentiment snažno je prisutan, a Ameriku se optužuje da je nakon Drugoga svjetskog rata u svijet unijela polarizaciju i nametnula svoju hegemoniju. "Divljačke kapitalističke sile" optužuju se za širenje sukoba i militarizma u svijetu, kao i za "sukob identiteta, kultura, civilizacija, uz sukob siromaštva i bogatstva". Kao poseban krivac za svjetske nevolje prozvan je George W. Bush, čije se ime u manifestu spominje češće nego Alahovo.

Autori koji su izučavali Hezbolah zamijetili su snažan ideološki aspekt te organizacije:

Zakat, izdvajanje sredstava u dobrotvorne svrhe, jedan je od pet stupova islama koji nijedna organizacija, pa ni Islamska država, koja identitet gradi na islamu ne može zanemariti.

8 Prva inačica Hezbolahova Manifesta nastala je 1985. i imala je više religijskog sadržaja. http://www.lebanonrenaissance.org/assets/ Uploads/15-The-New-Hezbollah-ManifestoNov09.pdf (pristupljeno 22. prosinca 2015). 
"Budući da je okupio siromašne šijitske mase, neki ga analitičari nazivaju 'avangardnom protuburžoaskom strankom' i 'proleterskom strankom s islamskim manifestom'" (nav. u: Kasapović 2016: 245). Šijiti su bili "najsiromašniji i najneobrazovaniji dio (libanonskog) društva" (Kasapović 2016: 227). Kada se pojavila organizacija koja je pokazala zanimanje za njihove socijalne potrebe, očekivano je bilo da će podržati njezino širenje i jačanje. Od 1992. Hezbolah sudjeluje na parlamentarnim izborima u Libanonu, a džihadističku retoriku zamijenio je političkim porukama prihvatljivima izvan kruga radikalnih islamista:

"Prije izbora, u svojemu izbornom programu i drugim dokumentima te istupima najviših dužnosnika proglasio je islamsku državu u Libanonu utopijskim idealom koji se ne može nametnuti vjerski i kulturno tako različitoj zemlji. Nakon 1992. redovito je sudjelovao na parlamentarnim izborima, a i u izvršnoj vlasti, te je modificirao svoju izvornu ideologiju. O Libanonu govori kao o 'našoj zemlji' u kojoj ima mjesta za sve 'duhovne obitelji', to jest za sve vjerske zajednice. Priznao je ustavnu demokraciju kao najbolji politički sustav za Libanon te 'slobodu vjerovanja, prakticiranje vjerskih obreda i izražavanja, slobodu političkoga i sindikalnog djelovanja te slobodu tiska uz poštovanje identiteta i općih normi'" (Kasapović 2016: 247).

Čak i kada govori o uništenju svoga glavnog neprijatelja, židovske države, Hezbolah ne zaziva masovno istrebljenje židovskog naroda, nego predlaže rješenja $s$ kojima bi se mnogi nemuslimani, poput gorljivijih pristaša protukolonijalizma i protuimperijalizma, mogli suglasiti. ${ }^{9}$ Hezbolah, makar javno, ne

9 Kasapović (2016: 247) navodi kako Hezbolah ne govori o "bacanju Izraela u more" zagovara ni nasilno širenje islama. Hasan Nasralah je, primjerice, u intervjuu 1986. objasnio da Hamas želi ukloniti kolonijalizam "iz ove regije", a nikako nametati islamsku vjeru silom (Noe 2007: 32). Slično kao Hamas, Hezbolah vidi područje svoga djelovanja na zemljopisno ograničenu prostoru. Osim Palestine, to je ponajprije Libanon, a potom i Sirija koju smatra saveznicom jer njom od 1971. vlada obitelj Asad, sljedbenica alavitskog ogranka šijizma. Nasralah se u govoru u Bejrutu 2005. pozivima za očuvanjem slobodnoga i demokratskog Libanona, među ostalim, obratio i francuskom predsjedniku Jacquesu Chiracu tražeći od njega da pomogne u zaštiti "naše povijesne i posebne veze sa Sirijom". Govor je održan nakon ubojstva Rafika Haririja, kada je Hezbolahu prijetila primjena Rezolucije 1559. Vijeća sigurnosti iz 2004. kojom se Libanon poziva da uspostavi suverenost na cijelome svom teritoriju, što je podrazumijevalo izbacivanje sirijske vojske iz zemlje, ali i razoružanje Hezbolaha. Pozivanjem na "demokratsku tradiciju" i "duh istinske zapadne demokracije" Nasralah je od Francuske zatražio odbacivanje te Rezolucije, a govor je završio riječima "Živio Libanon!" i "Živjela Sirija!" (Noe 2007: 325-327).

\section{Kampanja Al Kaide}

Al Kaida je u ljeto 2010. pokrenula časopis Inspire te do početka 2016. objavila 14 brojeva. U uredničkom uvodniku prvog broja navedeno je da je časopis namijenjen muslimanima s engleskoga govornog područja. No već na sedmoj stranici, u rubrici Questions we all should be asking, otvaraju se teme koje se često pojavljuju u zapadnim medijima i ne tiču se samo muslimana. Tako se tvrdi kako je razlog prisutnosti ame-

nego "želi 'riješiti' židovsko pitanje tako da se Židovi vrate u zemlje iz kojih su došli u Palestinu". 
ričke vojske u Iraku lažno prikazan svijetu. Postavlja se i pitanje zašto se Georgeu W. Bushu ne sudi za zločine protiv čovječnosti. Osobito je zanimljiv članak The Way to Save the Earth koji potpisuje Osama Bin Laden. U uvodu članka piše: "Ovo je poruka cijelom svijetu o onima koji izazivaju klimatske promjene i opasnostima koje one izazivaju - namjerno ili nenamjerno - te što... moramo učiniti. Govor o klimatskim promjenama nije ekstravagantna špekulacija: to je opipljiva činjenica koju ne umanjuje to što je pohlepni čelnici velikih korporacija zamućuju" (Inspire 1: 8). Autor ističe Jamesa E. Hansena, stručnjaka NASA-e, i Noama Chomskog kao primjere uglednih autoriteta čije bi savjete trebalo slijediti, dok su Bush ml. i Kongres prokazani kao "stvarni krivci za udar na globalnu klimu".

Posljednji broj Inspirea (14: 19-23) sadržava članak The Blacks in America u kojemu su Sjedinjene Države prikazane kao rasistička država. Policijska ubojstva crnaca stavljena su u kontekst "arogantnog stava današnje anglosaksonske generacije prema svim vrstama ljudi, a osobito prema crnim Amerikancima". Autor u zaključku islam prikazuje kao religiju koja zabranjuje rasnu diskriminaciju te poziva na osnivanje udruga civilnog društva, odnosno "političkih skupina koje će vršiti pritisak na vlast". One bi "otvorenim građanskim pristupom, a ne militantno", demonstracijama i građanskim neposluhom, vršile pritisak na vlast da zaustavi represije protiv crnaca, agresiju na muslimane i podršku Izraelu. U Inspireu (1: 57) ima referencija iz islamskih kanonskih tekstova, ali i zanimljiva poruka o tome kako su borci pošli u džihad ne zato što ih je unovačila Al Kaida, odnosno zato što bi bili potaknuti džihadističkim motivima, nego zbog "američkih zločina" ili "krstarećih raketa i kazetnih bomba kojima (Amerikanci) u Jemenu ubijaju žene i djecu". Po- sebno mjesto zauzimaju ojađenost zbog "okupirane Palestine," židovske medijske spletke i cionistički utjecaj na američku politiku (Inspire 4: 10). Slični su tekstovi i teme u većini brojeva Inspirea. Pristaše se ne vrbuju samo religijskim argumentima nego i navođenjem ovozemaljskih zala, kakvo je materijalizam, te nepravdi, poput rasizma, imperijalizma i različitih oblika segregacije (Inspire 2: 22).

"Zapad podupire vrijednosti poput jednakosti, slobode i ljudskih prava kao fasadu za skrivanje svoga stvarnog lica imperijalizma i pohlepe, ali je (napad) 11. rujna učinio ono što naše riječi nisu mogle. On je svijetu pokazao stvarnost, a Zapad pokazao u njegovu stvarnom svjetlu. Abu Graib, Guantanamo Bay i tajna neredovita izručenja svijetu su pokazali američko shvaćanje ljudskih prava" (Inspire 7: 13-14).

U sklopu obrazloženja napada 11 . rujna, autor članka Iran and Conspiracy Theories Abu Suhail opaža da o tom činu postoji "mnoštvo teorija urote" prema kojima iza njega stoji američka vlada ili izraelski Mosad. Potom se obrušava na tadašnjega iranskog predsjednika Ahmadinedžada i iransku vladu jer promiču ta "smiješna uvjerenja", optuživši ih da je njihov protuamerikanizam patvoren, a da su oni akteri dvolične "političke igre" (Inspire 7: 4). Zamjetna je eklektičnost navedenih argumenata, budući da su ta pitanja i teme nerijetko bliskiji lijevo-liberalnima društvenim aktivistima, pristašama teorija urote ili poluprofesionalnim "geostratezima" nego muslimanskim vjernicima. Može se reći da ciljna skupina Al Kaidine propagande jesu predani muslimanski vjernici, ali i nezadovoljnici, marginalizirane društvene skupine, ideološki zanesenjaci te muslimani koji više zajedničkoga imaju sa sekularnim buntovnicima protiv korumpiranih političkih establišmenata zapadnih država nego s radikal- 
nim istovjercima. U Inspireu (9: 23-24) važno mjesto imaju i članci u kojima se objašnjavaju tehnike pravljenja eksplozivnih naprava te se čitatelji potiču na terorističke napade na mete u državama u kojima žive. ${ }^{10}$

\section{Kampanja Islamske države}

Komunikacijska kampanja Islamske države ${ }^{11} \mathrm{u}$ dvije se ključne točke razlikuje od komunikacijskih kampanja Hamasa, Hezbolaha i Al Kaide. Prvo, Islamska država u svojima medijskim kampanjama pokazuje potpunu nezainteresiranost za stvaranje ikakva pozitivnog imidža ili simpatija za svoje ciljeve među nemuslimanima. Vrlo sličan stav pokazuje i prema muslimanima koji su zainteresiraniji za ideološka nego vjerska pitanja i prema onima koji, uz islamsku vjeru, njeguju načela humanizma i humanosti. To se isprva može učiniti nečime što se podrazumijeva, jer je teško očekivati da bi, primjerice, europski nemuslimani ili sekularizirani/tradicionalni muslimani imali mnogo simpatija za Islamsku državu. No nije tako. Kako je vidljivo iz navedenih uzoraka medijskih nastupa drugih islamističkih skupina, one se pozivaju i na ideološke i socijalne razloge svoje borbe, čime su stekle značajan broj simpatizera koji s njima nužno ne dijele religijske dogme ili metode borbe. To je jedan od razloga zbog kojega u njihovima komunikacijskim kampanjama nasilje koje primjenjuju prema neprijateljima rijetko zauzima udarni prostor, s iznimkom nasilja u okršaju s naoružanim vojnicima (poglavito izraelskima i američkim). Zlostavljanje civila i zarobljenika uglavnom je skriveno od javnosti. Nasuprot tome, Islamska

10 Primjerice, članak Make a bomb in the kitchen of your mom (Inspire 1: 33-40). Poseban se naglasak stavlja na "inicijative pojedinaca" koje su činile važan dio muslimanske borbe u povijesti (Inspire 2: 19).

11 Više o Islamskoj državi kao političkom fenomenu u: Havel 2015: 27-35. država od osnutka je objavljivala snimke i fotografije sadističkih smaknuća zarobljenih vojnika (Dabiq 3: 21) i civila, među kojima su bili novinari, humanitarni radnici te osobe optužene da su homoseksualci, preljubnici, vračari, razbojnici i osobito apostati (murtaddun) (Dabiq 3: 12-14). ${ }^{12}$ Brutalna, beskrupulozna bestijalnost s kojom pripadnici Islamske države vrše smaknuća, a uključuje odrubljivanje glava, razapinjanje, spaljivanje i gaženje tenkom, bilježena je kamerama, često uz visoku kvalitetu produkcije, odjela za promidžbu Al Hayāt, i objavljivana na društvenim mrežama i u "ulaštenom časopisu" Dabiq (Hosken 2015: 24). ${ }^{13}$ Među najjezivijima su egzekucije koje izvode djeca. ${ }^{14}$ Ta su glasila objavila i obnovu srednjovjekovnoga islamskog postupanja prema nemuslimanima: jedni se pretvaraju u roblje te prodaju i kupuju (Dabiq 4: 14-17), ${ }^{15}$ a drugi se pretvara-

12 U opisu egzekucije klana optužena za nepoštivanje šerijata i napad na borce Islamske države nalaze se referencije na rašidunske kalife Abu Bakira i Omera te hadisi iz Buharijeve i Muslimove zbirke (Dabiq 5: 23 i 6: 31).

13 Djeca, katkad s downovim sindromom, korištena su u terorističkim napadima i egzekucijama, a bila su i žrtve seksualnog zlostavljanja i prije proglašenja kalifata, odnosno dok se skupina nazivala Islamskom državom Iraka (Hosken 2015: 145).

14 http://www.dailymail.co.uk/news/article-3162110/ISIS-child-executioner-ignores-prisoners-pleas-spare-shoots-headwithout-hesitating-Shocking-footageshows-Islamic-State-s-evil-spread-generation.html; http://www.thesun.co.uk/sol/ homepage/news/6974689/ISIS-savagesforce-girl-12-to-execute-five-women-in-asickening-new-low.html (pristupljeno 12. ožujka 2016).

15 Katkad se stjecao dojam da se uništavanju spomeničke baštine pod zaštitom UNESCO-a pridavala veća pozornost nego pokoljima kršćana i Jezida. U članku The Revival of Slavery, u kojemu se obrazlaže porobljavanje Jezida, autor navodi da su angažirani islamski teolozi i povjesničari kako bi 
ju u zimije čiji životi ovise o plaćanju džizije Islamskoj državi. Mediji Islamske države bilježe i uništavanje vrijednih kulturnih spomenika te trijumfalno objavljuju snimke i fotografije ruševina, izazivajući zgražanje civiliziranog svijeta. ${ }^{16}$ Protukolonijalizam, protuimperijalizam i protuamerikanizam, kao i staleške, nacionalne, rasne, segregacijske i klimatske pritužbe u kampanji Islamske države do kraja 2015. načelno se uopće ne pojavljuju. ${ }^{17}$ To se odnosi čak i na protucionizam, jednu od najomiljenijih islamističkih tema: ${ }^{18}$ prva javna prijetnja Izraelu izrečena je tek u prosincu 2015. u audio-zapisu kalifa El Bagdadija. Njegova je prijetnja objašnjena nekoliko mjeseci kasnije u jednom biltenu na arapskom. U članku Bet El Makdis ${ }^{19}$ ponajprije je pitanje šerijatskog prava autor objašnjava kako džihad protiv Ži-

utvrdili jesu li Jezidi otpadnici od islama, što se kažnjava smrću, ili je njihova religija izvorno zasebna, pa se mogu ostaviti na životu kao roblje. U članku Slave-Girls or Prostitutes?, objavljenu u rubrici "Od naših sestara", autorica objašnjava kako je posjedovanje kafirskih ropkinja za seks sukladno šerijatu te navodi da ih je Ali Ibn Abu Talib, četvrti rašidunski kalif, imao devetnaest (Dabiq 9: 44-49).

16 V. prikaze uništenja hrama u Palmiri (Dabiq 11: 32-33) i šijitskog svetišta (Dabiq 2: 12-17).

17 Još je Muhamed uveo društvenu jednakost među muslimanima, bez obzira na podrijetlo, narodnost, rasu, stalež i društveni položaj koji su imali u vrijeme osobne ili opće džahilije. Muslimani plemenita i neplemenita roda, bogati i siromašni, pred Alahom su jednaki, pa se, simbolizirajući tu jednakost, tijekom hadža svi odijevaju u jednaku odjeću. Islamska država oslanja se na tu tradiciju egalitarizma (Dabiq 1:7) kao na nešto što se u umetu podrazumijeva.

18 Al Kaida smatra "uništenje Izraela" jednim od svojih najvažnijih ciljeva (Byman 2015: 47), što vrijedi i za niz drugih bliskoistočnih džihadističkih organizacija, uključujući Hezbolah i osobito Hamas.

19 Bet El Makdis je jedno od muslimanskih imena Jeruzalema. dova nije važniji od džihada protiv drugih nevjernika. Kritici je izvrgnut stav muslimana koji zbog posvećenosti oslobađanju Palestine pristaju uz ideologije strane islamu, poput marksizma i komunizma, što Islamska država definira kao asabijah. Štoviše, autor upozorava na to kako prednost pred borbom protiv nevjernika ima borba protiv arapskih apostata (murtaddun) i arapskih režima. Muslimanski čitatelj tu prepoznaje djelo po kojemu je poznat prvi kalif Abu Bakir (632-634), a to je vraćanje u okrilje umeta arapskih plemena koja su se nakon Muhamedove smrti pobunila protiv kurejšitskog vodstva i napustila islam. Prvi je kalif protiv njih poveo Rat ridde, murtadduni su poraženi, a osnaženi umet pod zapovjedništvom drugog kalifa Omera osvojio je krajeve od Perzije do sjeverne Afrike. Teško je previdjeti analogiju između ambicije kalifa El Bagdadija i ranoislamske, za pitanja kalifata normativne povijesti. Kronologija biranja neprijatelja ključna je: razjedinjeni se umet ne može širiti. Zato je uništenje Izraela važno pitanje za muslimane, ali ga treba promatrati u kontekstu opće borbe muslimana protiv nemuslimana, a ne kao jedini ili glavni cilj (Havel 2016: 76). ${ }^{20}$

Borba za vlast na demokratskim izborima - što čine Hamas i Hezbolah te time svoje političko postojanje čine legitimnim pred međunarodnom zajednicom - za Islamsku je državu nezamisliva zato što se ideološki, nacionalni i slični motivi smatraju vjerski nelegitimnima,

${ }_{20}$ Časopis Al-Naba: http://www.memrijttm. org/isis-jihad-in-palestine-does-nottake-precedence-over-jihad-elsewhere. html\#_ednref5 (pristupljeno 31. ožujka 2016, pregledano 26. studenoga 2017. Za pristup se potrebno registrirati na MEMRI). Časopis na arapskom: https:// azelin.files.wordpress.com/2016/03/theislamic-state-e2809cal-nabacc84_-newsletter-22e2809d.pdf (pristupljeno 26. studenoga 2017). 
a oštri prijekori upućeni su samo ideologiji pacifizma. ${ }^{21}$

Drugo, Islamska država sve do studenoga 2015. nije ohrabrivala pojedince na izvođenje terorističkih napada po svijetu, nego na hidžru i doseljenje na teritorij Islamske države. ${ }^{22}$ Stoga "Al Kaida ponajprije predstavlja protuteroristički izazov, dok Islamska država predstavlja i vojni izazov" (Byman 2015: 225). Imperativ doseljenja izložen je, primjerice, $\mathrm{u}$ članku Nema života bez džihada, a nema džihada bez hidžre (Dabiq 3: 31). I tu se Islamska država obraća muslimanima koji posjeduju znanja o ranoislamskim tekstovima, konceptima i povijesti, jer

${ }^{21}$ U članku "Islam je religija mača, a ne pacifizma" (Dabiq 7: 20-24) objašnjena je etimologija riječi islam prema kojoj ona znači podložnost, a ne mir odnosno "salām", premda je korijen obje riječi isti.

22 U Dabiqu br. 12, objavljenu nakon terorističkog napada u Parizu 13. studenoga 2015. i rušenja ruskoga putničkog zrakoplova iznad Sinaja, takva se vrsta terorizma pozdravlja. Uvodni članak završava porukom da svaki "muvahid", koji je spriječen napraviti hidžru, obnovi baj'ah i pod zastavom kalifata napadne "križare" i njihove saveznike, odmetnute muslimane, na mjestu gdje se nalazi, čak i ako je sam. Članak završava prijetnjom "križarima" i navodom iz Kurana 9:52: "Mi očekujemo da vas Alah kazni sâm ili našim rukama! Pa čekajte, i mi ćemo s vama čekati!" (Dabiq 12: 3). Čini se da su "vukovi samotnjaci" Islamsku državu stavili pred svršen čin te nije mogla postupiti drukčije do pozdraviti njihova djela. No hidžra ostaje prvi i najbolji izbor. U posljednjem Dabiqu (13: 6-8), u članku "Kill the Imāms of Kufr", autor se obrušio na islamske teologe Saudijske Arabije nakon egzekucije zatvorenika 2. siječnja 2016, među kojima su bili i šeici Abu Jandal Al Azdi i Hamd Al Humajdi. Članak je zaključio zazivanjem Alahova blagoslova na "vitezove samotnjake Kalifata Arapskoga poluotoka", pozivajući ih da ubiju spomenute teologe prema kuranskim ajetima 9:5 i 2:194. U Dabiqu (6:3-4) pozdravljen je teroristički čin pristaše Islamske države Mana Harona Monisa u Sydneyju u prosincu 2014. je i prvi muslimanski politički entitet, onaj u Medini, započeo hidžrom a ne džihadom. Islamska država načelno se ne obraća društvenim nezadovoljnicima muslimanske vjere, što ne znači da i oni nerijetko smisao života ne pronalaze u identificiranju s kalifatom, čak ako o njemu ne znaju mnogo. Dok je propaganda Al Kaide usmjerena uvelike prema "vukovima samotnjacima" koje nastoji potaknuti da uspostave nepovezane ćelije i izvode samostalne terorističke napade (Inspire 2: 19), Islamska država promiče dalekosežnu religijsku, vojnu i političku viziju (Harleen 2014: 1-2). To je vizija državnosti pod središnjim vodstvom kalifa, a ne vizija fragmentirana sustava napadača potaknutih kojekakvim motivima i vođama. Ključna poruka Islamske države do konca 2015. - poziv muslimanima u svijetu da se dosele u Islamsku državu - nije se odnosila samo na borce nego i na visokoobrazovane osobe, poput liječnika, učitelja i inženjera. To uglavnom nisu osobe $s$ margina društva, nego stručnjaci dobro integrirani u društva u kojima žive. Napuštanje sigurnog doma, posla i životnog standarda te prelazak s obitelji u ratnu zonu na Bliskom istoku mogući su gotovo isključivo na temelju dubokoga i iskrenoga religijskog uvjerenja. Jasno je da su ranjive i društveno neintegrirane osobe lakši plijen islamističke propagande, no Islamska država takvima se ne obraća kao žrtvama nepravednih društava ili sustava nego ponajprije kao muslimanskim vjernicima.

Propagandno glasilo Dabiq osmišljeno je za promicanje upravo takve poruke. ${ }^{23}$ Tekstovi u njemu obiluju islamskom terminologijom koja je transkribirana s arapskoga na engleski jezik, uglavnom bez prijevoda. Autori se referiraju na vjerske teme kao na nešto

\footnotetext{
${ }^{23}$ Dabiq je izlazio od proglašenja kalifata 2014, a kada je 2016. Islamska država izgubila sirijski grad po kojemu je časopis nazvan, zamjenjuje ga Rumiyah.
} 
o čemu čitatelj već mnogo toga zna pa ne treba prevoditi pojmove i objašnjavati koncepte. Kuranska poglavlja (sure), kojih je 114, iznose se u obliku imena, a ne brojeva. Pitanja vezana za kalifat stoljećima su činila važan dio islamske misli i kolektivnog sjećanja, a kako je nada u njegovu obnovu u širem umetu, zajednici muslimana cijelog svijeta, uvijek postojala, ona čini glavnu nišu za promicanje Islamske države. Neočekivana masovnost "Arapskog proljeća" dio je arapskih muslimana podsjetila na izvorno jedinstvo umeta te su ga počeli percipirati kao mogući uvod u obnovu univerzalnog kalifata (Israeli 2014: 36). Neuspjeh "Arapskoga proljeća" mlade je $\mathrm{u}$ arapskome muslimanskom svijetu potaknuo na ponovno promišljanje identiteta i ograničenih mogućnosti života pod bliskoistočnim režimima. Dio ih je potražio alternativna rješenja i ciljeve, pa je nadu u obnovu minule slave islama bilo lako razbuditi. Islamska je država mnogima u trenutku identitetske i materijalne krize ponudila zamamna ovozemaljska i celestijalna obećanja kojima su njihova očekivanja artikulirana i raspaljena te, makar u prvom dijelu, katkad $\mathrm{i}$ ispunjena (Havel 2015: 27-35).

\section{Rašidunska načela u kampanji Islamske države}

Odmah poslije proglašenja Islamske države pokrenuta je medijska kampanja kako bi se muslimani diljem svijeta suočili s pitanjem nije li nakon stoljećâ poniženja i razdora (fitne) došlo vrijeme obnove islamske snage i časti. Okosnica medijske kampanje bila je ideja da se oni mogu obnoviti samo kroz kalifat, a ne oslanjanjem na inicijative pojedinaca i širenjem ilegalnih fragmentiranih džihadističkih ćelija. Na naslovnici prvog broja Dabiqa nalazi se ključna poruka: "Povratak kalifata". Kalifat nije prikazan kao još jedan entitet u mozaiku zavađenih arapskih muslimanskih skupina, nego kao autentičan nastavak prijašnjih kalifata, a time i jedini vjerski legitiman oblik političke vlasti svekolikoga islamskog svijeta.

Kako bi se shvatila privlačnost te ideje među muslimanima, nužno je poznavati koncept kalifata kao vjerskoga, povijesnog i političkog fenomena (Hosken 2015: 19). To je znanje na sekularnom Zapadu prilična rijetkost, jer kalifat kao potentan politički čimbenik odavno ne postoji, a u sklopu izučavanja islama njegova se vjerska važnost najčešće ne prepoznaje. To ne čudi jer u Kuranu i Muhamedovu sunetu - s iznimkom šijitske tradicije koja zagovara autoritet Alija Ibn Abu Taliba i njegovih potomaka, no šijitska je tradicija ovdje nerelevantna pitanje Muhamedova nasljednika nije adresirano. U promišljanjima o kalifatu muslimani se stoga ponajprije referiraju na ranoislamsku povijest. Umet je nakon Muhamedove iznenadne smrti 632. morao iznaći ad hoc rješenje problema vodstva. Kako nisu postojali ni naputak ni kriterij izbora, za Muhamedova sljednika, kalifa, postavljen je Abu Bakir (632-634), jedan od prvih i najvjernijih Prorokovih sljedbenika. On je bio Prorokov punac, suputnik u hidžri ${ }^{24} \mathrm{i}$ osoba poznata po čestitosti. Kasnija mu je islamska tradicija dodala naslov As Sidik, odnosno Istinoljubivi ili Iskreni. U Dabiqu (8: 12) se citira hadis prema kojemu, "da Abu Bakir nije bio imenovan kalifom, Alaha se na zemlji ne bi štovalo". ${ }^{25}$ Drugog kalifa, Omera Ibn El Kataba, za nasljednika je pred smrt predložio Abu Bakir, a zajednica je, poznavajući Omerove sposobnosti i vrline, taj savjet prihvatila (Holt, Lombton i Lewis 1978:

\footnotetext{
${ }^{24}$ Hidžra ili hidžret je Muhamedov bijeg iz Meke u Medinu 622.

25 Ideja da je ispravnost izbora kalifa presudna za postojanje bogoštovlja nije uobičajena $\mathrm{u}$ ranoislamskoj tradiciji, te je u tom pogledu očita snažna religijsko-politička manipulacija Islamske države.
} 
63-64). ${ }^{26}$ Tijekom desetogodišnjega Omerova kalifata (634-644) islamski se imperij proširio kao nikad prije. Još od Muhamedova doba muslimani su na politički i vojni uspjeh umeta gledali kao na izraz božanske naklonosti, a na sebe kao na "inkarnaciju božanske volje u povijesti" (Badeau 1959: 72). Štoviše, najvažnijim duhovnim uspjehom umeta smatralo se širenje islamske političke vlasti. Orijentalist i religiolog Peters (1991: 298) u svome je glasovitom članku Quest of the Historical Muhammad objasnio da je - dok je potvrda kršćanske vjere u Uskrsu - potvrda islamske vjere u njezinoj golemoj i zapanjujućoj inicijalnoj ekspanziji (v. i Kramer 1995: 75). Ta je tvrdnja ključna za razumijevanje kalifata, jer autor vojno i političko širenje islama prikazuje kao conditio sine qua non teološke ispravnosti te religije u percepciji njezinih sljedbenika. Peters povezuje islamsko osvajanje teritorija s islamskom soteriologijom, što je na tragu ranoislamskih tekstova, uključujući Kuran, u kojima je vojno pobjeđivanje uvjetovano pravovjernošću. ${ }^{27}$ Zbog dojmljivih vojnih pobjeda islamska je tradicija kalifa Omera počastila najzvučnijim naslovom među Rašidunima - Al Faruk - što, prema etimologiji aramejskog jezika, znači "Spasitelj" (Crone i Cook 1977: 5).

Pristanak i opći konsenzus vjernika (rida va-džama'a) te duljina ili starost u islamskoj vjeri postali su široko prihvaćena načela izbora kalifa tijekom Omerove vladavine (Sharon 1983: 39, 1984:

26 Al-Tabari (god. 11, str. 145-148). Oskudni su izvori o načinu izbora prvih kalifa, a među povjesničarima ne postoji suglasje o njemu (o dvojbama o Omerovoj biografiji v. Encyclopaedia of Islam, sv. 10, str. 818-819).

27 Takvo se viđenje ne odnosi samo na islam. U Suri 30, koja se naziva Rim, muslimani žaluju zbog pobjede Perzijanaca, štovatelja vatre, nad Rimljanima (Bizantincima), sljedbenicima Knjige. Alah u Suri 30:3-4 nagoviješta bizantsku pobjedu nakon koje "veselit će se pravovjerni". Više o tome u: El-Kardavi 2003: 10-11.
121), premda je već Abu Bakir postao kalifom zahvaljujući njima. Omer je pred smrt imenovao izborno tijelo, šuru, koje je izabralo trećeg kalifa, Osmana Ibn Afana. ${ }^{28}$ Nakon Osmanove smrti, prema sličnom načelu, kalifom je postao Ali Ibn Abu Talib. Nijedan rašidunski kalif nije svoj naslov naslijedio nego su ga izabrali bliski suradnici, a muslimani koji u vrijeme izbora nisu bili nazočni, naknadno su mu prisegnuli na odanost (baj'ah). Tek su kalifi nakon Alija - umajadski, koji su držali vlast do 750, a potom abasidski, bagdadski i osmanski - na položaj dolazili nasljeđivanjem, spletkama ili silom. Sukobljavanje suparničkih dinastija posljednjih je godina Rašiduna dovelo do fitne, raskola umeta ${ }^{29}$ najveće kušnje i zla što su pogodili islam u ranoj povijesti. ${ }^{30}$ Razjedinje-

28 Svi su kalifi bili iz kurejšitskog plemena iz kojega je potjecao Muhamed, ali ne iz istoga klana. Osman je potjecao iz mekanskog klana Umajada, Omer iz klana Banu Adi, a Abu Bakir iz klana Banu Taim. Ali je pak potjecao iz klana Banu Hašim kao i Muhamed. To što pripadnost ili nepripadnost određenom klanu nije bila važna u izboru prve trojice kalifa govori u prilog tomu da je njihov izbor bio ishod drugih čimbenika, a ne onih koji su bili uvriježeni u vrijeme džahilije (Donner 2010: 132-133). No pripadnost kurejšitskom plemenu s vremenom je definirana nužnom za legitimnost kalifa pa se na nju poziva i kalif El Bagdadi.

29 Nakon Alijeve smrti 661. općeprihvaćeno je da sljedeći kalif bude njegov stariji potomak Hasan, pa ga je prvi umajadski damaščanski Muavija podmitio kako bi se odrekao kalifskog naslova u njegovu korist. No Alijeva dinastija nastala je u kontekstu pojave Prorokova doma (ahl el-bait), što je fenomen koji se razvijao unutar polemike o pravu vodstva (Sharon, 1986: 169-184, 1991: 115-152). Zagovaranje legitimnosti kalifske dinastije Alijevih potomaka fenomen je sui generis i ne može se primijeniti na opravdavanje umajadske, abasidske ili neke druge dinastije. Bagdadske i osmanske kalife često su nasljeđivala braća (Lewis i Churchill 2012: 217).

30 Više o određivanju događaja zbog kojeg je došlo do fitne u: Juynboll 1973: 142-159. 
na zajednica zaustavljena je u osvajanju svijeta. Tijekom slijedećih stoljeća umet je političku lojalnost iskazivao različitim vođama i vladarima: od klanskih i plemenskih do nacionalnih i državnih. No lojalnost bilo kome drugome osim kalifu (ili izvorno Muhamedu) smatra se strančarenjem (asabijah) i činom izdaje. Asabijah je u predislamskome arapskom društvu bio pozitivan koncept, a označavao je lojalnost obitelji, klanu ili plemenu. Asabijah među muslimanima dugo nije bio osobito važan politički termin, budući da kalif ne postoji već gotovo stoljeće, a u prethodna četiri stoljeća vladali su Turci, a ne Arapi. Islamska je država ponudila novo tumačenje asabijaha. U Dabiqu (8: 3) nalazimo hadis iz Muslimove zbirke, ${ }^{31}$ prema kojemu Muhamed kaže kako onaj koji pogine podržavajući asabijah umire u džahili$j i{ }^{32}$ čime se taj koncept aktualizira u političkome i soteriološkom smislu. No asabijah se u tekstovima Islamske države ne tumači u izvornom značenju lojalnosti rodbinskoj i plemenskoj zajednici, nego u smislu pristajanja uz bilo koju političku teoriju, režim, svjetonazor ili ideologiju: sekularizam, nacionalizam, patriotizam, demokraciju pa čak i protucionizam (Dabiq 8: 39-56). Vjerska je

Fitna je jedan od ključnih događaja za razumijevanje ranoislamske povijesti, okončanja rašidunskog kalifata i kasnijih pogleda na političku vlast nad umetom. Koncept je važan za dublje razumijevanje islamske političke misli i islamske hereziologije. Riječ ima više značenja od kojih se u zapadnoj literaturi najčešće spominje "građanski rat", što je više opis posljedice, a ne definicija koncepta. Spominje se i u Kuranu u smislu kušnje. Više o značenju imena i upotrebi u islamskoj povijesti i tradiciji u Encyclopaedia of Islam, sv. 2, str. 930-931.

31 Muslimova zbirka hadisa jedna je od najuglednijih među sunitima. Više o islamskom kanonu u: Havel 2013: 74-78.

32 Džahilija (neznanje) razdoblje je arapske povijesti prije adventa islama, a u ovom kontekstu znači da je onaj koji umire u $d \check{z} a$ hiliji završio u paklu. dužnost muslimana distancirati se i od protukolonijalizma kao protjerivanja zapadnih sila, poglavito SAD-a, s muslimanskoga Bliskog istoka, što je bio glavni cilj Al Kaide (Byman 2015: 170, 47). Prema uvjerljivome suvremenom tumačenju asabijaha, sve su to značajke džahilije.

Legitimnost kalifata Islamske države i kalifa El Bagdadija kao amirul-muminina Islamska je država u svojoj komunikacijskoj kampanji gradila na tri načela povezana s Ar Rašidunima. Prvo, kalif je Arapin koji potječe iz plemena Kurejšita. Kalif se oslovljava kao "Amirul-Mu'minin Abu Bakr al-Husayni al-Qurashi al-Baghdadi" (Dabiq 1: 7). Kalifovo ime "Al-Qurashi", koje nije bezrazložno stavljeno ispred imena pod kojim je poznat, pokazuje da potječe iz kurejšitskoga plemena iz kojega su potjecala sva četvorica Ar Rašiduna i sam Prorok. Slično vrijedi i za "al-Husayni", što podrazumijeva potomstvo iz loze imama Huseina, sina kalifa Alija, i naizgled je uz ime El Kurejši zalihosno, jer je Huseinov potomak nužno i Kurejšit. No nije svaki Kurejšit iz Prorokova doma, ali Huseinov potomak jest (Dabiq 10: 22). Kurejšitsko je podrijetlo nužan uvjet legitimnosti kalifa. Postoji, doduše, i drukčije mišljenje. Ibn Haldun (13321406) u svojemu glasovitom djelu $\mathrm{Mu}$ kadima tumači kako ustrajavanje na kurejšitskom rodoslovlju kalifa predstavlja asabijah, a da je izvor legitimnosti kalifova autoriteta njegova politička i vojna moć (Ardiç 2002: 315-324). Nakon što su osmanski sultani preuzeli naslov kalifa, važnost kurejšitskoga podrijetla zapostavljena je i zanemarena. Do ukidanja kalifata 1924. Turci nisu postavljali pitanje važnosti kurejšitskog podrijetla, ali je to među arapskim muslimanima bio općepoznat uvjet. Možda se Osama Bin Laden nikad nije pokušao proglasiti kalifom - uspostava kalifata jedan je od dugoročnih ciljeva Al Kaide (Byman 
2015: 48-49) - zato što se njegovo podrijetlo, premda arapsko, nije moglo povezati s kurejšitskim korijenima. ${ }^{33}$ Stoga su talibani, koji nisu Arapi, u Afganistanu proglasili emirat, a ne kalifat. Talibanski vođa Mula Omar nije bio iz kurejšitskog plemena pa nije mogao proglasiti kalifat (Dabiq 10: 22).

Drugo, kalifat je pod Abu Bakirovim vodstvom, poglavito na početku, postigao goleme vojne uspjehe. Osvajanje Mosula nije slučajno bilo prijelomnica u preobrazbi Islamske države Iraka i Al Šama (arap. Daiš) u Islamsku državu te proglašenje kalifata, jer je njime naočigled muslimanskog svijeta ispunjen, prema mišljenju mnogih, najvažniji od triju spomenutih kriterija. Propagandni mehanizam kalifata to je osvajanje pripisao božanskoj naklonosti i sveopćemu muslimanskom zajedništvu, što predstavlja suprotnost fitni.

"Amirul-muminin je kazao: 'O, muslimani posvuda, radosna vam vijest! Očekujte dobro! Visoko podignite glave, jer danas - po Alahovoj milosti - imate državu i kalifat koji će vratiti vaše dostojanstvo, prava i liderstvo.

To je država u kojoj su Arapin i nearapin, bijelac i crnac, istočnjak i zapadnjak braća.

To je kalifat koji je okupio Kavkažanina, Indijca, Kineza, Sirijca, Iračanina, Jemenca, Egipćanina, Magrebljanina, Amerikanca, Francuza, Nijemca i Australca. Alah im je srca sjedinio, te milošću njegovom postadoše braća, ljubeći jedan drugoga zbog Alaha, stojeći u jednom rovu, braneći i čuvajući jedan drugoga i žrtvujući se jedan za drugoga...

33 Bin Laden i Abu Musab Al Zarkavi nisu imali formalno teološko obrazovanje te ih sljedbenici nisu prepoznavali kao religijske vođe (Byman 2015: 72), dok je Abu Bakir doktorirao islamske znanosti na Islamskom sveučilištu u Bagdadu.
Kada bi kraljevi iskusili ovakav blagoslov, kraljevstva bi svoja napustili i borili se za tu milost. Stoga sva slava i zahvalnost pripadaju Alahu" (Dabiq 1:7).

Naprasni rast broja i snage pristaša kalifata nakon te spektakularne pobjede, te takvih i sličnih tumačenja nije bio neočekivan jer se sličnosti s rašidunskim kalifatom nisu mogle ignorirati, a Islamska država od početka se referirala na izjave rašidunskih kalifa. Teritorijalni i vojni gubici Islamske države 2016. i 2017. taj su aspekt sličnosti s Rašidunima bitno umanjili pa i poništili. To se vidjelo u promjeni kampanje 2016, uključujući gašenje Dabiqa nakon što je istoimeni grad izgubljen.

\section{Terminologija Islamske države}

Bitnu stavku u komunikacijskoj kampanji Islamske države čini terminologija. Zapadne države i organizacije koje su u islamističkim krugovima dosad uglavnom opisivane kao kolonizatori islamske zemlje nazivaju se "križarima". Sloboda govora naziva se "idolom" (Dabiq 9: 3), a idolopoklonstvo (širk) najveći je grijeh u islamu. Time je ideološki diskurs posve preoblikovan u vjerski. No El Bagdadi ne naziva se samo kalifom nego i amirul-mumininom (Dabiq 1: 11, 8: 7-8), što ističe njegov objedinjeni vjersko-politički autoritet, pri čemu politički autoritet proizlazi iz religijskoga, kao kod Ar Rašiduna, a ne obratno, kao kod osmanskih kalifa.

To vodi $\mathrm{k}$ trećoj točke kalifove sličnosti s Ar Rašidunima, odnosno k pitanju njegova izbora. Kalifa izabire šura, izborno tijelo, pa se njegov autoritet temelji na konsenzusu vjernika (Havel 2015a). Abu Bakira je izabrao uži krug suradnika. Muslimanski klerici, poput Jusufa El Kardavija, poriču njegovu legitimnost upravo zbog nepostojanja svjetskog konsenzusa muslimana o pitanju 
uspostave tog kalifata. No ni u izboru rašidunskih kalifa nisu sudjelovali svi muslimani nego određeno izborno tijelo čiju je odluku s vremenom prihvatila većina umeta. Zato je Abu Bakir, kao i kalifi prije njega, od muslimana tražio baj'ah - prisegu odanosti. Muslimani koji naprave hidžru iskazuju je ipso facto. No u ukupnome muslimanskom stanovništvu oni su manjina. Zato je Islamska država uputila poziv muslimanima diljem svijeta da prisegnu na odanost novom kalifu. I koncept baj'aha preuzet je iz formativnog razdoblja islamskog društva. Odanost Muhamedu iskazivali su pojedinci koji se zbog nekog razloga nisu mogli doseliti u Medinu. Prema hadisu iz Muslimove zbirke koji se referira na Omera Ibn El Kataba, Muhamed je upozorio na to da "svaki koji umre a da mu oko vrata nije baj'ah, umire smrću džahilije" (Dabiq 11: 10). Nadalje, u vrijeme rašidunskog kalifa Abu Bakira, baj'ah se tražio od arapskih plemena u vrijeme ratova protiv apostazije (ratova ridde) kako bi se razlučila plemena koja prihvaćaju Muhameda kao proroka od plemena koja su slijedila nekoga drugog, "lažnog" proroka ili proročicu iz svoje sredine. Glavno postignuće prvog kalifa bilo je upravo suzbijanje apostazije na Arapskom poluotoku te ponovno ujedinjavanje arapskih plemena pod plaštem islama. Rašidunski kalifi izabrani su dogovorno, a drugi kalif Omer za izbor sljedećega kalifa postavio je šuru koju su činili Prorokovi ashabi (najbliži suradnici). Ostali dijelovi umeta kasnije su iskazivali lojalnost kalifu kroz baj'ah. Prisezanje islamističkih skupina i pojedinaca u Egiptu, Libiji, Tunisu, Afganistanu, Bosni i Hercegovini, Francuskoj, Belgiji, Švedskoj i drugdje na lojalnost kalifu El Bagdadiju znači prepoznavanje da je on amirul-muminin te bitno osnažuje njegovu legitimnost utemeljenu na idžmi. Što širi dio umeta prihvati legitimnost, kalif je legitimniji. Idžma al-uma, koju je kalif El Bagdadi postizao kroz baj'ah, sve je više postajala okosnicom njegova autoriteta, zbog čega Islamska država katkad naglašava baj'ah nauštrb hidžre. Prihvaćanje izabranog kalifa od strane muslimana koji nisu nazočili ili sudjelovali u izboru postojalo je i u vrijeme Ar Rašiduna, a prema kasnijoj tradiciji ono se podrazumijevalo (Mottahedeh 2001: 50-51). Te tri značajke krasile su Ar Rašidune i stoga su ključan argument u uvjeravanju muslimana kako je došlo vrijeme ne samo obnove islamske slave nego i konačne pobjede nad kafirima, što je dio božanskog obećanja muslimanima za posljednja vremena.

Islamska država u svojim je glasilima ukazivala na to kako je njezin kalifat odraz izvornog kalifata i donositelj eshatološkog doba. U obje te teme bitno se razlikuje od islamističkih skupina koje se rijetko ili nikako ne bave eshatologijom - ta je tema općenito bliža šijitskome nego sunitskom vjerskom diskursu - ali ni kalifatom u neposrednom smislu u svojstvu njegovih nositelja. ${ }^{34}$ Islamska država uspjela je pak svoje postojanje prikazati kao povratak na temeljna načela Ar Rašiduna, i to u obliku kakav možda nije viđen od kraja rašidunskog razdoblja. Tri načela - kurejšitsko podrijetlo, impresivna vojna postignuća i izborna legitimnost, odnosno stjecanje kalifskog naslova na temelju izbora a ne obiteljskog slijeda ili nasilnog svrgavanja prethodnika - od 661. nisu bila objedinjena u jednoj osobi. Abu Bakir El Bagdadi načelno je prvi pretendent tijekom više od tisuću tristo godina koji je do kraja 2015. razmjerno argumentirano mogao zahtijevati da ga se prepozna kao amirul-muminina sličnoga Ar Rašidunima. Islam je, kao i druge religije s opsežnim kanonskim opusom i bogatom tradicijom, otvoren za niz tumačenja, od

\footnotetext{
34 Iznimka je donekle Hamas kao palestinska podružnica Muslimanskog bratstva, a Muslimansko bratstvo djelomice je osnovano radi obnove kalifata četiri godine nakon njegova gašenja.
} 
kojih su mnoga međusobno suprotstavljena. Ne poričući da postoje i drugi načini tumačenja, ne može se zanemariti kako se Islamska država argumentirano oslanjala na ranoislamsku tradiciju i kanonske tekstove. U njima se može pronaći sve: od ustroja državnog sustava, fiskalne i porezne politike do proglašavanja muslimanskih protivnika kalifata murtaddima, odnosa prema inovjercima i načina borbe s oponentima. Muslimanskim protivnicima Islamske države to nije promaknulo. Uredništvo časopisa Haqiqah (1: 10), koji su pokrenuli muslimanski teolozi kako bi mogli javno iznositi suprotstavljene argumente, već je u prvom broju nastojalo citatima iz islamske tradicije i Kurana opovrgnuti legitimnost Abu Bakira, primjerice na temelju njegove ambicioznosti da postane vladarom. ${ }^{35}$ Važnost uključivanja umjerenih ulema koji kane idejno odnosno teološki suzbiti vjerodostojnost kalifata Islamske države kroz informacijske i komunikacijske kampanje teško je precijeniti.

\section{Zaključak: autentičnost religijskog fanatizma}

Temelj Islamske države čini pozivanje na ranoislamska načela i oponašanje ranoislamskih praksi u svakoj sferi privatnoga i društvenog života, bilo to oportuno ili ne, te na uvjerljivoj interpretaciji kanonskih spisa i tradicije u kontekstu današnjih bliskoistočnih i svjetskih zbivanja. Islamska država to čini kroz komunikacijsku kampanju koja uvelike vjerno izražava vjerska i politička stajališta te

35 Abu Bakirovo proglašenje kalifom već početkom srpnja 2014. odbacio je i Međunarodni savez ulema koji predvodi Jusuf El Kardavi, duhovni vođa Muslimanskog bratstva. Oni su naglasili kako je za kalifat potreban konsenzus svih muslimana (https://www.middleeastmonitor.com/ news/middle-east/12567-prominent-scholars-declare-isis-caliphate-null-and-void, pristupljeno 8. veljače 2016). skupine. Golema strateška prednost Zapada, a ponajprije službi koje rade na suzbijanju sigurnosne prijetnje, upravo je u tome što Islamska država u komunikacijskoj kampanji vjerodostojno izlaže svoje motive, ciljeve i načine njihova postizanja. Zapad dosad tu prednost nije dovoljno iskoristio. Sekularni, liberalni Zapadnjaci uglavnom olako odbacuju religijske argumente koji se temelje na fanatičnom prizivanju srednjovjekovnih načela i eshatologije, jer ih smatraju odveć bizarnima da bi bili autentični. Tako je potkraj 2014. zapovjednik američkih postrojba za posebna djelovanja na Bliskom istoku, general-bojnik Michael K. Nagata, priznao da američka vojska i obavještajna zajednica ne razumiju ni pokret ni ideje Islamske države zbog kojih je ona tako opasna. ${ }^{36}$ No argumenti Islamske države izneseni u komunikacijskoj kampanji vrlo su autentični. $\mathrm{Na}$ autentičnosti argumenata temelji se autentičnost kalifata, što ciljna skupina zna prepoznati. To bi morala znati i sigurnosna zajednica, koja bi trebala iscrpno analizirati podatke do kojih može doći jednostavnim praćenjem kampanje. Razina religijskog fanatizma, odnosno iracionalnosti i bizarnosti ideje kalifata, ne stvara veličinu koja je obrnuto razmjerna razini autentičnosti te ideje. Boljim razumijevanjem parametara te jednadžbe stječu se nezanemarivo goleme strateške prednosti. Jedan je od tih parametara percepcija komunikacijske

36 http://www.nytimes.com/2014/12/29/us/ politics/in-battle-to-defang-isis-us-targetsits-psychology-.html?_r=0 (pristupljeno 11. veljače 2016). Zanimljivo je da je bivši ravnatelj američkih obavještajnih službi NSA-a i CIA-e Michael V. Hayden (2016) u svojoj knjizi vrlo malo prostora posvetio islamu i džihadizmu te ih nije ni pokušao objasniti u kontekstu povećanja sigurnosne spremnosti SAD-a. Prema kazalu imena, riječ "islam" pojavljuje se na dvije stranice, kao i Islamska država Iraka i Sirije, pojam "džihadisti" na tri (Hayden 2016: 443), dok se "islamizam", "džihadizam", "radikalizam" i "eshatologija" uopće ne spominju. 
kampanje u ciljnoj skupini, odnosno omjer uvjerljivosti i dvojbe koji se dade iščitati.

A dvojba glede Islamske države u ciljnoj skupini kojoj je kalifat namijenio komunikacijsku kampanju ne odnosi se poglavito na to je li ona autentična ili nije, nego je li ona sukladna Kuranu i sunetu ili nije. Naime, kanonski spisi i tradicija na koje se Islamska država poziva poznati su u većini islamskih zajednica, pa i u onima koje su zbog drukčijeg tumačenja uistinu tolerantne prema muslimanskim neistomišljenicima i pripadnicima drugih religija, primjerice u Hrvatskoj i Bosni i Hercegovini. ${ }^{37}$ Islamska država nudi radikalna, nasilna i džihadistička tumačenja, često ističući eshatološke teme i očekivanje apokalipse. Eshatologija je općenito važan dio diskursa Islamske države. Časopis Dabiq nazvan je prema gradu Dabiqu u sjevernoj Siriji u kojemu će se, prema hadisu iz Muslimove zbirke, održati posljednja bitka između muslimana i kršćana, odnosno "Rimljana". U toj će bici jedna trećina muslimana pobjeći, druga izginuti kao šehidi, a treća izvojevati pobjedu. Pobjednička muslimanska vojska potom će zaratiti protiv lažnog mesije u Šamu (Siriji), a vodit će ih Isa Ibn Mirjam (Dabiq 1:5). Privlačnost eshatologije za odane sljedbenike većine religija - uključujući sekte koje su se u povijesti pojavljivale na kršćanskom Zapadu - nije novost pa u tom kontekstu treba promatrati i promidžbu Islamske države usmjerenu muslimanima.

No eshatologija nije tema kojoj je u tradicionalnoj sunitskoj misli pridavana veća pozornost. Ona je mnogo bliža ši-

$37 \mathrm{Na}$ hrvatskom jeziku postoji opsežna Muhamedova biografija utemeljena na Ibn Ishakovoj Sirat Rasul Allah koju je napisao bivši muftija Islamske zajednice u Hrvatskoj i u kojoj su bez ustezanja iznesene mnoge epizode iz Muhamedova života na koje se pozivaju različite radikalne islamističke skupine (Omerbašić 2002). jitskoj teološkoj misli: očekivanje dolaska ili povratka skrivenoga dvanaestog imama okosnica je vjere većine šijita još od vremena Mahdijeva misterioznog odlaska u "veliku skrovitost" 941. godine. Aktivno očekivanje apokalipse u sunitskom je svijetu nakon ranoislamskoga rašidunskog razdoblja jenjavalo. Istodobno, vjera u "posljednja vremena" važna je dogma i sunitskog islama. Istina, malo je tko tu dogmu uzimao u obzir u osmišljavanju političkih programa - nasuprot nekima drugim dogmama, kao što je podjela svijeta na darul-islam i darul-harb - no ona je prisutna i u Kuranu i u hadisima te je poznata muslimanima. Isticanje neposredne važnosti te dogme u tumačenju aktualnih društvenih i političkih zbivanja jedan je od ključnih uvjeta razumijevanja kalifata Islamske države. No eshatologija je istodobno i razlog za suzdržanost mnogih muslimana prema Islamskoj državi. Politički aktivizam potaknut eshatologijom - premda one koji ga prihvate čini fanatičnima sljedbenicima - nije dio srednje struje sunitske tradicije.

Nemuslimani, ali i mnogi muslimani među kojima su i neki zagovornici radikalizma, poput duhovnog vođe Muslimanskog bratstva Jusufa El Kardavija, Islamsku državu smatraju novotarijom nespojivom s "istinskim" duhom islama i šerijatom. Komunikacijska kampanja Islamske države velikim je dijelom usmjerena na opovrgavanje te teze kako bi muslimani diljem svijeta, umjesto "novotarija" Islamske države, kritički propitivali tradiciju srednje struje. Prikazivanje svih oblika islama koji odbacuju kalifat Islamske države kao sinkretičnih, eklektičnih zastranjenja od vjere, inficiranih pogubnim neislamskim idejama, ili kao asabijaha, moćan je argument kojim su pokrenute tisuće muslimana prema Siriji. Za njegovo opovrgavanje u medijsku polemiku s Islamskom državom potrebno je uklju- 
čiti islamske teologe koji će na temelju istih tekstova i tradicije na koje se poziva Islamska država ponuditi drukčije zaključke. Pristajanje uz novotarije drugi je najveći grijeh u islamu, odmah nakon širka. Pitanje s kojim su suočeni muslimani koji promišljaju te teme glasi: je li Al-Ḥayāt umješnom propagandom uspio religijske novotarije Islamske države prikazati kao standarde vjere ili je zbiljske novotarije koje su se kroz povijest ukorijenile kao standardi u islamskom svijetu raskrinkao kao herezu? Njima se u komunikacijskoj kampanji Islamske države ne postavljaju pitanja o tome što misle o raznima ideološkim, političkim, ekonomskim, segregacijskim, okolišnim ili nacionalnim pitanjima - sve je to tek asabijah. Pitanje čak nije ni opravdavaju li ili ne jeziva i nečovječna postupanja prema civilima i zarobljenicima. Spaljivanje živoga zarobljenoga jordanskog pilota predstavljeno je kao kažnjavanje murtadda i "križara", uz prigodne hadise, tradiciju i kuranski ajet: "A ako budete kažnjavali, kažnjavajte onako kako ste vi bili kažnjavani" (En-Nahl 16: 126), popraćen fotografijama ljudi navodno spaljenih u zračnim napadima na Islamsku državu (Dabiq 7: 5-8). Dvojba s kojom se suočavaju muslimani izloženi kampanji Islamske države gotovo je isključivo vjerska. Nametanjem vjerskog diskursa Islamska je država argumente sekularnog Zapada, humanizma pa i zdravog razuma učinila irelevantnima. To je vjerojatno njezin najveći propagandni uspjeh. 


\section{Literatura}

Al-Tabari. 1987-1997. The History of alTabari. New York: State University of New York Press.

Ardıç, Nurullah. 2002. Genealogy or Asabiyya? Ibn Khaldun between Arab Nationalism and the Ottoman Caliphate. Journal of Near Eastern Studies. (71) 2: 315-324.

Badeau, John S. 1959. Islam and the Modern Middle East. Foreign Affairs. (38) 1: 61-74.

Byman, Daniel. 2015. Al Qaeda, the Islamic State, and the Global Jihadist Movement: What Everyone Needs to Know. Oxford i New York: Oxford University Press.

Byman, Daniel. 2016. Fight the Islamic State by Targeting Its Affiliates. Foreign Affairs. (95) 2: 76-85.

Crone, Patricia, Cook, Michael. 1977. Hagarism: The Making of the Islamic World. Cambridge: Cambridge University Press.

Donner, Fred M. 2010. Muhammad and the Believers: At the Origins of Islam. Cambridge i London: Belknap Press of Harvard University Press.

El-Kardavi, Jusuf. 2003. Islam i muslimani u savremenom svijetu. Mostar: Islamski kulturni centar.

El-Kardavi, Jusuf. 2010. Savremene fetve 2. Sarajevo: El-Kalem.

Encyclopaedia of Islam. 1986-2004. Leiden: E. J. Brill.

Harleen, Gambhir K. 2014. Dabiq: The Strategic Messaging of the Islamic State. Institute for the Study of War. 1-12.

Havel, Boris. 2013. Arapsko-izraelski sukob: religija, politika i povijest Svete zemlje. Zagreb: Naklada Ljevak.

Havel, Boris. 2014. Haj Amin al-Husseini: Herald of Religious Anti-Judaism in the Contemporary Islamic World. The Journal of the Middle East and Africa. (5) 3: 221-243.
Havel, Boris. 2015. Islamska država nije samo "takozvana": političko-vjerska propaganda i pitanje autentičnosti kalifata. Političke analize. (6) 22: 27-35.

Havel, Boris. 2015a. Politički islam, sekularizam i demokracija. U: Špehar, Hrvoje. (ur.). Europski sekularni identiteti. Zagreb, Fakultet političkih znanosti, str. 51-76.

Havel, Boris. 2016. Postosmanski Orijent: od fragmentacije do asabijaha, $s$ osvrtom na arapsko-izraelski sukob. Europske studije. (2) 3-4: 49-82.

Hayden, Michael V. 2016. Playing to the Edge: American Intelligence in the Age of Terror. New York: Penguin Press.

Holt, P. M., Lambton, Ann K. S., Lewis, Bernard (ur.). 1978. The Cambridge History of Islam. Cambridge: Cambridge University Press.

Hosken, Andrew. 2015. Empire of Fear: Inside the Islamic State. London: Oneworld Publications.

Israeli, Raphael. 2014. Hatred, Lies, and Violence in the World of Islam. New Jersey: Transaction Publishers.

Jensen, Michael Irving. 2009. The Political Ideology of Hamas: A Grassroots Perspective. London: I.B.Tauris.

Juynboll, G. H. A. 1973. The date of the great fitna. Arabica. (20) 2: 142-159.

Kasapović, Mirjana. 2016. Libanon. U: Kasapović, Mirjana. (ur.). Bliski istok: politika i povijest. Zagreb: Fakultet političkih znanosti, str. 219-260

Kasapović, Mirjana. 2016a. Palestina. U: Kasapović, Mirjana. (ur.). Bliski istok: Politika i povijest. Zagreb: Fakultet političkih znanosti, str. 261-311.

Kramer, Martin S. (ur.). 1995. Middle Eastern Lectures. Tel Aviv: Moshe Dayan Center for Middle Eastern and African Studies, Tel Aviv University.

Lewis, Bernard, Churchill, Buntzie Ellis. 2012. Notes on a Century: Reflections 
of a Middle East Historian. New York: Viking Penguin.

Mottahedeh, Roy P. 2001. Loyalty and Leadership in an Early Islamic Society. New York: I. B. Tauris.

Noe, Nicholas. (ur.). 2007. Voice of Hezbollah: The Statements of Sayyed Hassan Nasrallah. London i New York: Verso.

Omerbašić, Ševko. 2002. Poslanik $i$ njegovi ljudi: povijesni dokument o Božjem poslaniku i ashabima. Zagreb: Mešihat islamske zajednice u Hrvatskoj.

Peters, F. E. 1991. The Quest of the Historical Muhammad. Journal of Middle East Studies. 23: 291-315.

Sharon, Moshe. 1983. Black Banners from the East: The Establishment of the 'Abbāsid State: Incubation of a Revolt.
Jeruzalem: The Magnes Press, The Hebrew University i E. J. Brill.

Sharon, Moshe. 1984. The Development of the Debate around Legitimacy of Authority in Early Islam. Jerusalem Studies in Arabic and Islam. (5) 2: 121-141.

Sharon, Moshe. 1986. Ahl al-bayt - People of the House. Jerusalem Studies in Arabic and Islam. (8) 1: 169-184.

Sharon, Moshe. 1991. The Umayyads as Ahl Al-Bayt. Jerusalem Studies in Arabic and Islam. (14) 1: 115-152.

Stav, Arieh. (ur.). 2001. Israel and a Palestinian State: Zero Sum Game? Shaarei Tikva: Ariel Center for Policy Research.

Wood, Graeme. 2015. What ISIS Really Wants. The Atlantic. (315) 2: 78-94.

\title{
Communication Campaign of the Islamic State: Dabiq, 2014-2015
}

\begin{abstract}
Contents and messages of the Islamic State's communication campaign from the moment Caliphate was declared in July 2014 and throughout 2015, differ significantly from communication campaigns launched by other main Middle Eastern Islamist groups. Better quality of production and hitherto unfathomable brutality is the first impression which IS's campaign leaves. More important, however, are the ideas, motives and goals articulated and advertised through the same campaign. Primary target audience of the IS's campaign are Muslims familiar with Islamic canonical texts, normative traditions and authoritative interpretation of Muslim religion and law. The campaign's goal is to persuade its audience that through the Islamic State, long-awaited Caliphate has been reestablished, that Abu Bakr Al-Baghdadi is the legitimate Amir al-Mu'minin. Flagrantly absent from IS's communication campaign in 2014 and 2015 were references to ideological issues, or social, economic, colonial, national or racial grievances, which have been essential in communication campaigns of most other major Middle Eastern Islamist groups. What is more, the Islamic State demonstrates ample lack of interest in portraying any positive image whatsoever about itself among non-Muslims and moderate Muslims in the West and elsewhere. Should the West recognize authenticity of the IS's communication campaign, through which it has been presenting its motives, means and goals, a more serious scrutiny of their campaign might prove useful in battling the idea of the Caliphate and preventing growth of its influence both in the Islamic world and in the West.
\end{abstract}

Key words Islamic State, Middle East, Islamism, terrorism, caliphate, communication campaign 
